Revue francophone sur la santé et les

territoires

Pandémie, crises et perspectives : lectures

territoriales de la Covid-19 | 2021

\title{
Mapping Covid-19: what narrations?
}

\section{Nicolas Lambert}

\section{(2) OpenEdition}

1 Journals

\section{Electronic version}

URL: http://journals.openedition.org/rfst/855

DOI: $10.4000 /$ rfst.855

ISSN: 2492-3672

\section{Publisher}

Espaces et SOciétés (UMR 6590)

\section{Electronic reference}

Nicolas Lambert, "Mapping Covid-19: what narrations?", Revue francophone sur la santé et les territoires [Online], Pandemic, crises and perspectives: territorial readings of Covid-19, Online since 18 February 2021, connection on 06 April 2021. URL: http://journals.openedition.org/rfst/855 ; DOI: https://doi.org/ $10.4000 /$ rfst.855

This text was automatically generated on 6 April 2021.

\section{c) (i) (2)}

La Revue francophone sur la santé et les territoires est mise à disposition selon les termes de la Licence Creative Commons Attribution - Pas d'Utilisation Commerciale - Partage dans les Mêmes Conditions 4.0 International. 


\title{
Mapping Covid-19: what narrations?
}

\author{
Nicolas Lambert
}

1 Since the work of John Brian Harley, it has been commonly accepted that maps are not simply objective representations of the real, but carry within them a particular form of ideological discourse, based on ideas and values (Harley, 1989). In fact, regardless of the methods and techniques used to produce them, maps are first and foremost the result of intentional processes of communication. In this paper, we propose to describe three interactive and dynamic maps on the Covid-19 epidemic that we have developed over the last few months. Each time, we unravel and analyze the underlying cartographic choices. In other words, we propose to decipher, beyond the technical and computer elements, how the cartographer's intention, his assumptions, his points of view, are present in the final image to form a meaningful graphic narrative. In addition, in a reproducible research approach, the data used is public and all source codes are available online.

2 The first map provides a cartographic representation, at the scale of the French departments, of the weekly positivity rate of Covid-19 screening tests. Produced in Javascript with the D3.js library, this interactive map adopts the governmental rhetoric of "red zones" and "green zones" detailed in Juliette Morel's recently published article (Morel, 2020). In cartography, colors and their connotations are indeed powerful ways to deliver clear messages. Here, green evokes serenity, authorization and security, while red represents evil, forbidden or danger in a fairly common way.

The second mapping tool, based on hospital data provided by Santé Publique France, provides a set of maps updated daily on several indicators: number of deaths, number of hospitalizations, people in intensive care and resuscitation, number of radiations. These maps are designed according to two strong methodological orientations. Firstly, each data is presented in a decomposed form so that each dot represents one person (when possible). Then, to make visible each dot without overlay, they are moved away from each other according to a displacement algorithm, until they form clusters that extend well beyond the underlying administrative delineations. If these colored spots thus formed give a fairly good account of the quantities represented, they mainly illustrate the idea of contagion and the spread of an overheated health system. 
Figure: Mapping the covid epidemic
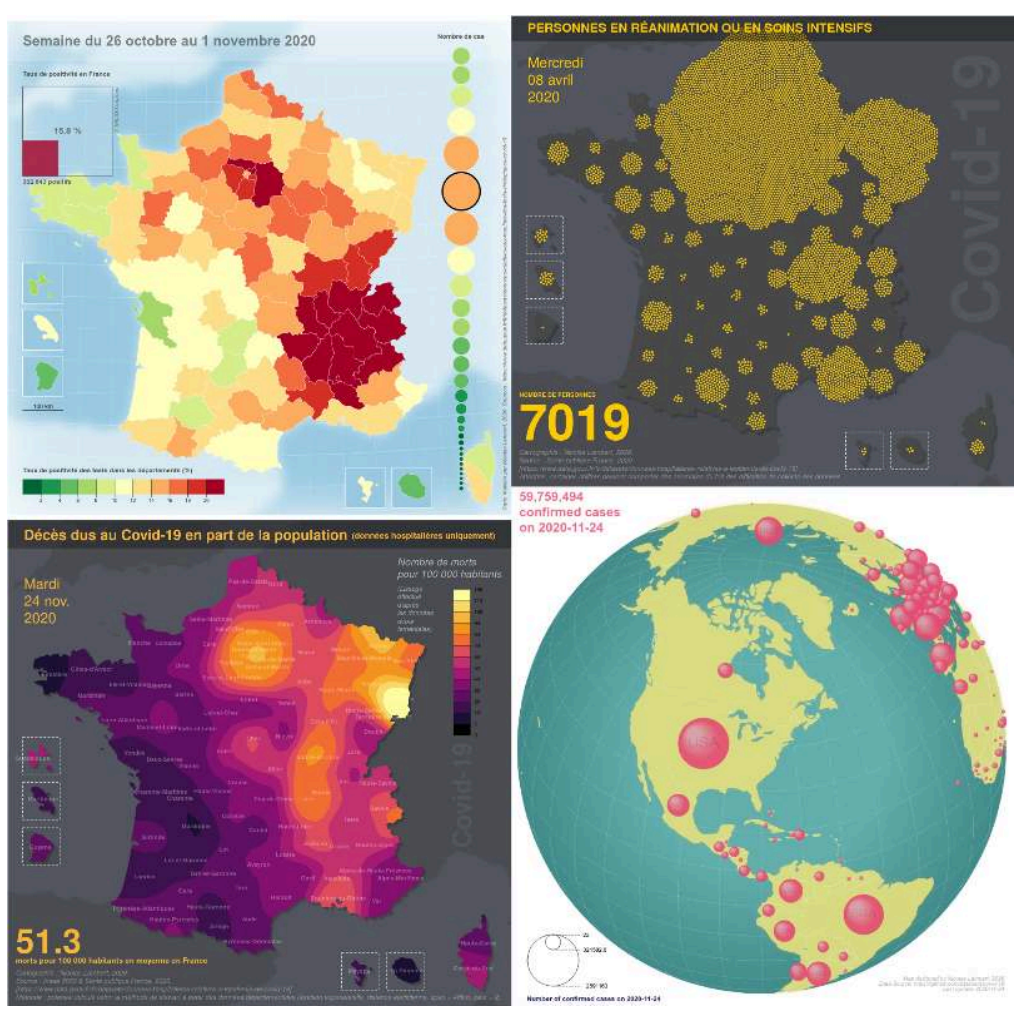

4 A few weeks after its publication, and with the same intention of breaking away from administrative units, this tool was completed by a smooth animated map showing the evolution and spread of the epidemic on French territory.

5 Finally, the third interactive map proposes a change of scale. Designed in D3.js, this map takes the shape of a globe on which symbols representing three variables are displayed: the number of deaths, the number of cases, and the number of recoveries. Beyond the issues related to graphic semiology as such, the rhetorical aspects of these maps are above all related to the "globe" shape. This idea has its source in the work of Élisée Reclus. Strongly against maps for teaching geography, he argued, in a realistic approach, for the material construction of huge globes, the only way to represent the World without distorting it. Moreover, display a globe is also a way to show the unicity of the world without any bias, without center or margins. In short, a means to give to even a unified humanity facing as a whole the pandemic of Covid-19.

6 In the end, the three maps and cartographic tools that are presented in this paper demonstrate that beyond the treatments and modes of representation used, what determines their narrative form is above all the cartographer's intention, his will to produce a discourse that makes sense. 


\section{BIBLIOGRAPHY}

Harley, J. B. (1989). Deconstructing the map. Cartographica: The international journal for geographic information and geovisualization, 26(2), 1-20.

Morel J. (2020). Chronique d'une communication cartographique ratée. Déconstruction critique des cartes du gouvernement français pendantla crise de la Covid-19 au printemps 2020. JSSJ Justice Spatiale. http://www.jssj.org/article/chronique-dune-communication-cartographiqueratee-deconstruction-critique-des-cartes-du-gouvernement-francais-pendant-la-crise-ducovid-19-au-printemps-2020/

\section{AUTHOR}

\section{NICOLAS LAMBERT}

Ingénieur de recherche en sciences de l'information géographique, UMS RIATE, CNRS. 